\title{
Budget institutions and taxation
}

\begin{abstract}
While a number of different studies have explored the effects of budgetary procedures and the centralization of the budget process on government debt, deficits and spending, few of them have explored whether such fiscal institutions matter for public revenue. This article argues that centralizing the budget process raises the levels of taxation by limiting the ability of individual government officials to veto tax increases in line with common-pool-problem arguments regarding public finances. Using detailed data on budgetary procedures from 15 EU countries, the empirical analysis shows that greater centralization of the budget process increases taxation as a share of GDP and that both the type of budget centralization and level of government fractionalization matter for the size of this effect. The results suggest that further centralizing the budget process limits government debt and deficits by increasing public revenues as well as constraining public spending.
\end{abstract}




\section{Introduction}

Interest has been growing in recent decades about how budget institutions - the procedures and rules that structure the process of preparing, enacting and implementing the public budget - affect government fiscal policy. Existing empirical contributions to that literature have focused primarily on developed democracies; ${ }^{1}$ but given the continuing concern with large government budget deficits and debt in many developed and developing countries, policymakers and researchers have turned their attention to how modified budget procedures might promote greater fiscal responsibility. Early attempts to do so include von Hagen and Harden (1995) and Alesina and Perotti (1996).

Recent scholarship generally confirms that more hierarchical, centralized budget procedures limit public deficits and debt accumulation (Hallerberg et al. 2007, 2009; de Haan et al. 2013) ${ }^{2}$ as well as growth in public spending (Martin and Vanberg 2013). Much of the literature on budget procedures and fiscal policy concerns how centralized budget procedures reduce the effect of policymaker fractionalization on the growth of fiscal policy aggregates (Hallerberg et al. 2009; Wehner 2010; de Haan et al. 2013; Martin and Vanberg 2013). More centralized budget procedures should therefore mitigate the so-called common-pool problem of public finance (Weingast et al. 1981; Velasco 2000), whereby fractionalization in the budget decision-making process (e.g., in the form of a multiplicity of ideologically distinct parties in government) leads to excessive public spending increases and, thus, larger public budget deficits and faster debt accumulation.

\footnotetext{
${ }^{1}$ See Alesina et al. (1999) for a study of the effects of different budgetary institutions in Latin America.

${ }^{2}$ For exception to these findings, see Perotti and Kontopoulos (2002).
} 
However, while the effect of more centralized and hierarchical budget institutions on government spending and government deficits seems established in the literature, the other central aspect of government finances - government revenue - has received much less attention. Much of the previous literature is based on the assumption that more centralized, hierarchical budget procedures affect government deficits by constraining public spending (Hallerberg et al. 2009, pp. 28-34), but it does not address government revenue (neither empirically nor theoretically).

This article argues that the centralization of the national budget procedure not only affects government spending, but also government revenue and, in line with the common-pool argument, that government fractionalization also matters for these dynamics. Since government coalition partners in a decentralized budget regime are incentivized to veto tax increases that disproportionally affect their constituencies, a more centralized regime, which strengthens the agenda-setting power of the finance minister, should lead to higher levels of national taxation for a given level of public expenditure, assuming that the finance minister wants to balance the public budget, and that his or her greater agenda-setting power makes it more difficult for individual cabinet members to veto tax increases that fall heavily on their own constituencies.

Fixed-effects estimates in a panel of 15 European Union (EU) countries for which detailed budgetary process data exists strongly confirm that argument. More centralized budget procedures increase taxation as a share of the gross domestic product (GDP). Rather than being solely a tool for limiting government size, a more centralized budget procedure seems to reduce public budget deficits through both expenditure and revenue channels. The extent of the tax-increasing effect of budget centralization is contingent on both the type of budget centralization and government 
fractionalization. In the case of budget centralization, which delegates budget procedure powers to the finance minister, greater government fractionalization actually increases the impact of budget centralization, as the status quo bias of increased veto-player fractionalization makes it more difficult to deviate from the finance minister's preferred level of taxation.

\section{Theory: Government budget procedures and tax-setting}

The theoretical reasoning behind the argument that increased budget centralization increases the level of taxation is based on simple theory of government budgeting and the assumption that a finance minister ${ }^{3}$ is concerned with balancing the public budget. The theoretical argument is presented in non-formal terms below as well as in simple formalization (see Appendix A in the supplementary material).

Consider a coalition government the members of which represent different constituencies (i.e., social groups and/or geographical units). The members are assumed to seek to advance the interests of their respective constituencies. ${ }^{4}$ When preparing the public budget, the members of government need to agree on sharing a fiscal burden in the form of taxation to finance already agreed increases in public spending, thereby achieving a more balanced budget.

\footnotetext{
${ }^{3}$ Or the minister responsible for preparing and implementing the public budget.

${ }^{4}$ This can be represented as either an ideological preference for serving their constituency or an interest in securing future electoral support.
} 
The fiscal burden can be spread over a number of tax instruments, each instrument affecting each coalition member's constituency differently; property taxes disproportionally affect homeowners, taxes on agricultural land disproportionally affect farmers, payroll taxes disproportionally affect wage earners and so on. Even more general taxes (e.g., consumption taxes, income taxes) tend to be borne more by some groups than others. Consumption taxes tend to hit low-income households relatively heavily, whereas income taxes, which are progressive in almost all countries, disproportionally affect high-income households. Almost all of the types of taxation employed in modern states thus affect some societal groups disproportionally.

In a non-hierarchical budgeting setting, changes to each type of taxation instrument—and therefore also tax increases — are decided individually. The government members must therefore agree on increases to each tax instrument to finance the budget. In this tax-setting situation, each government coalition member is incentivized to veto increases in the tax instruments that disproportionally affect their constituency. This dynamic will prevail even if each coalition member agrees that producing a certain amount of tax revenue is necessary, since it is possible to freeride on the taxation of the other coalition members' constituencies.

With a non-hierarchical or decentralized budget procedure, the increases in taxation will therefore be less than the agreed-to level of spending. The magnitude of this phenomenon increases as the coalition grows in number and each coalition partner represents a more exclusive constituency, since each tax instrument will affect each represented constituency more exclusively in the context of greater coalition fractionalization, while the opportunity to freeride the taxes levied on other coalition members' constituencies also increases from the perspective of the individual coalition 
member. Consequently, the level of taxation decreases as the number and diversity of the coalition's members increase. This argument is similar to the classical common-pool approach to public finances, although it tends to focus on public spending as the relevant fiscal variable (Velasco 2000; Hallerberg et al. 2009, pp. 24-28).

In the case of a more centralized budget procedure, however, the coalition government is presented with a taxation package prepared by the finance minister that balances the level of public spending. ${ }^{5}$ This assumes that the finance minister's agenda-setting power over the public budget proposal— and thus public expenditure - also translates into agenda-setting power over government revenue policies. The laws governing public revenues and public expenditures are obviously usually distinct, but the financing of existing and new public expenditure is usually part of the same process, at least in the budget preparation phase. Furthermore, in most developed democracies, the public tax administration and tax policy departments are part of the ministry of finance. Even in countries with a separate ministry of taxation (e.g., Denmark), the ministry of finance also oversees taxation policy and there is close coordination between the ministry of finance and the ministry of taxation, the former generally setting overall policy regarding taxation.

So in a situation where the budget procedure is centralized and the finance minister is charged with presenting a comprehensive public budget proposal for the cabinet, changes to tax policies to finance new expenditure will usually accompany this proposal. The finance minister is, thus, the central and empowered agenda-setter regarding taxation policy in a centralized budget procedure.

\footnotetext{
${ }^{5}$ The finance minister is implicitly assumed to be concerned with balancing the public budget.
} 
In the case of this centralized budget procedure, the coalition members must now agree to remove increases in the different taxation instruments from the budget rather than agreeing to increase taxation via the different instruments. This dynamic will bias against tax cuts, since the government coalition members must now agree to remove already-proposed tax increases. This logic also extends to the legislative phase in the budget process, where tax levels will be higher the less individual legislative actors (e.g., support/opposition parties) are able or incentivized to remove new or existing taxation items from the budget. This can be achieved via amendment limits or the rule that the budget proposal is voted on as a whole. These dynamics mean that, ceteris paribus, greater centralization of the budget process will increase the level of taxation. ${ }^{6}$ Furthermore, greater coalition fractionalization in terms of the number of parties and ideological differences will increase the impact of budget centralization on taxation. Here, the status quo bias of greater veto-player distance within the government (Tsbelis 2002) ${ }^{7}$ will make it harder for the government to reach agreement on removing taxation items from the finance minister's initial budget, which serves as the status quo budget.

\footnotetext{
${ }^{6}$ This line of argument resembles a situation where the government has fiscal room to implement tax cuts. Here, coalition members are incentivized to maximize cuts to their constituencies' tax payments while freeriding on the tax payments of other constituencies. This leads to a common-pool problem, where total taxes end up lower than planned. In contrast, the finance minister takes the total budget balance into account when deciding the tax cut for each tax instrument. Consequently, the tax raised from each instrument-and the total level of taxation-will be greater when the finance minister has greater agenda-setting power than in a decentralized budget regime. ${ }^{7}$ For a well-cited empirical study of the role of veto players in public budgets, see Tsebelis and Chang (2004).
} 
This line of argument provides the basis for two hypotheses.

H1: Further centralization of the budget process will increase the level of taxation.

H2: The impact of the centralization of the budget process increases with the fractionalization of the government.

The theoretical arguments above are similar to other models of fiscal policymaking in cabinets and the role of budgetary procedures (Hallerberg et al. 2009, pp. 24-34). However, the arguments in this article add a new aspect to the role of budget centralization. While a more centralized budget procedure might reduce public spending, it might also increase taxation, as the finance minister, who is responsible for balancing the budget by moderating spending and increasing revenue, is empowered relative to the other cabinet members in a more centralized budget procedure. The next section describes the data used to test the above hypotheses.

\section{Data and estimation}

The dataset that forms the empirical basis of the test of the effect of budget centralization on the

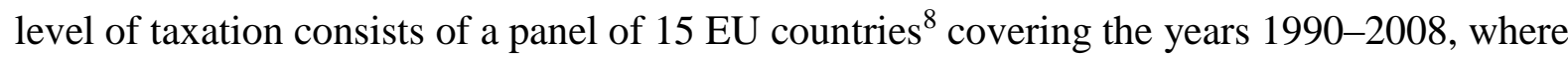
detailed data for the structure of the budget process exists. The central dependent level of interest is the level of taxation, which is measured as taxes as \% of GDP. Obviously, this variable measures relative tax revenues rather than changes to official tax policy (e.g., tax laws). Comprehensive data on changes to tax legislation is not readily available, however, and changes to official tax rates

\footnotetext{
${ }^{8}$ These are the "old" EU countries: Austria, Belgium, Denmark, Finland, France, Germany, Ireland, Italy, Luxembourg, Netherlands, Portugal, Spain, Sweden and the United Kingdom.
} 
might not always be fully representative of the actual taxes paid by citizens and companies (Slemrod 2004, pp. 1176-1177). The theoretical argument made in this article - that centralizing the budget procedure increases the power of the finance minister, who is interested in balancing public revenue and expenditure — should also be more valid for actual tax revenues rather than official tax rates. So especially since controls of the state of the economy are included in the later statistical estimates, tax revenue as \% of GDP should on average be able to capture differences in governments' de facto tax policies in countries over time and be more closely linked to the theoretical argument. The taxation data is from the OECD database.

To measure the level of budget centralization, I rely on Hallerberg et al. (2007, 2009), who have gathered detailed data on budgetary procedures and norms in the $15 \mathrm{EU}$ countries. The data is based on three different surveys carried out in the early 1990s and 2000s (Hallerberg et al. 2009, pp. 5657), and since the surveys record when changes to budgetary procedures are made, over-time variations in the budgetary procedures for the countries should be reflected in the data. ${ }^{9}$ I follow the classification suggested by these scholars and distinguish between delegation centralization and contracts centralization approaches when measuring budget centralization levels.

Delegation centralization consists of three subcomponents related to the finance minister's ability to control the budgetary process in the cabinet negotiation stage, the parliamentary stage and the budget implementation stage. Delegation centralization increases the more there are general budget

\footnotetext{
${ }^{9}$ According to personal correspondence with one of the authors, the data most reliably captures actual budget practices and rules until the 2008 financial crisis, which is therefore the end year of the panel. Excluding the years after 2004 (the year of the last survey) from the analysis yields largely similar results.
} 
constraints for the cabinet and the more the budget negotiation process assumes the form of a topdown process with the finance minister as the central agenda-setter. The level of delegation centralization in the parliamentary stage increases the less able and incentivized the parliament is to introduce amendments to the initial budget proposal and if expenditures and the budget itself are voted on in one session. With respect to implementation delegation, centralization increases with the ability of the finance minister to control the other ministers in the budget execution phase.

Contract delegation relates to the existence, time horizon and level of commitment to official fiscal targets that set guidelines for public expenditure development. The level of contracts centralization increases along with the length of the time horizon of the fiscal targets and the strength of the legal basis of these targets. The precise operationalizing of these variables is described in Hallerberg et al. (2009, pp. 52-75). ${ }^{10}$ Both measures of budget centralization are scaled to run from 0 to 1 , higher values denoting higher budget centralization levels.

Especially delegation centralization fits the theoretical arguments for why increased budget centralization should increase taxation levels. However, the existence of longer term and more binding fiscal targets should also enable the finance minister to balance the budget via taxation increases. Since the finance minister in this type of budget centralization still serves an important function as the guardian of the fiscal contract (Hallerberg et al. 2009, p. 51), the finance minister

\footnotetext{
${ }^{10}$ In this article, the delegation centralization index is equal to the authors' Delegation Index, while the contract centralization index is equal to the Fiscal Targets (Long-Term) index (Hallerberg et al. 2009, p. 74). The authors also construct a full Contracts Index, which includes aspects of the budget implementation. Replacing the one type of contracts index with the other yields mostly similar results (results available upon request).
} 
might argue that the removal of new taxation items by cabinet members and/or parliamentary actors would counteract the financing of the already-agreed-to levels of public spending established in the spending targets. This dynamic should also enable the finance minister to better introduce and implement tax increases with this type of budget centralization.

The indexes themselves deal with the centralization of the overall budget process and tend to focus on public expenditures. As argued in the theoretical section, however, this general budget centralization should also spill over into greater centralization and agenda-setting power vis-à-vis tax policy. Furthermore, some of the subcomponents of the indexes deal specifically with the centralization of tax policy, such as the existence of targets for tax levels in the case of contracts centralization (Hallerberg et al. 2009, p. 60) and whether parliament must approve of additional government revenue to finance additional expenditure in the case of delegation centralization (Hallerberg et al. 2009, p. 64). The indexes should therefore also capture the centralization of the budget procedure regarding taxation decisions.

The other central explanatory variable is the fractionalization of the incumbent government. To measure this, I rely on a measure of government fractionalization from the Database of Political Institutions. I use the variable checks, which is a continuous variable that increases by one for each additional party in the government coalition as long as the parties are needed to maintain a majority, and one for each member of the coalition that has an ideological position closer to the largest opposition party than the party of the chief executive (Cruz et al. 2016). This variable has the advantage of simultaneously measuring both the size and ideological fractionalization of the government. 
Apart from these main explanatory variables, I employ a number of political controls that could affect both the level of taxation and the main explanatory variables. As political controls, I control for the occurrence of a legislative election to account for a potential electoral cycle in taxation using data from the Database of Political Institutions (Cruz et al. 2016). I also include the share of cabinet members from leftwing parties to control for a partisan effect on the level of taxation using data from the Comparative Political Dataset (Armingeon et al. 2015). A number of economic controls are also included. One is PPP-adjusted GDP per capita in constant prices from the OECD database. To control for the general state of the economy and as a measure of the state of the business cycle, I use GDP growth from the OECD Economic Outlook 98. The dependent variable is measured in \% of GDP, so this control is necessary to ensure that a potential effect on tax levels is not due to changes in the denominator of the taxation variable. The state of the economy might also affect tax revenues, and increases or decreases in national income might be endogenous to changes in budgetary institutions. In the supplementary material (Appendix B), as an alternative measure of business cycle fluctuations, I use the output gap in \% of potential GDP taken from the OECD Economic Outlook 101. The core results using this alternative measure of business cycle fluctuations are similar to the main analysis.

Since the theoretical argument states that budget centralization will increase the level of taxation given the level of agreed upon government spending, I later include a control for the level of government spending measured by government outlays as \% of GDP. The source for this variable is also the Comparative Political Dataset. Descriptive statistics can be found in Table 1.

[Table 1 here] 
The estimation method used to test the hypotheses is ordinary least square with both country- and years-fixed effects. The country-fixed effects enable me to hold country-specific characteristics constant and to analyze deviations in taxation levels from the country mean. The year-fixed effects help eliminate the potentially endogenous effect of a general trend toward higher levels of taxation and greater budget centralization in the analyzed period as well as a general trend in the other independent variables (e.g., GDP per capita). Standard errors are clustered at the country level to address autocorrelation issues. The estimate can be seen in equation 1, where countries are indexed by $i$ and years by $t$. Budget centralization is the measure of budget centralization-either delegation or contracts - while Gov.frac. is the government fractionalization measure, which is interacted with the budget centralization measures in later specification in order to test Hypothesis 2. $X$ is a vector of controls, while $\gamma_{t}$ and $\delta_{i}$ are the year- and country-fixed effects, respectively.

$$
\text { Taxation }_{i t}=\beta_{1} \text { Budget centralization }_{i t}+\beta_{2} \text { Gov.frac }_{\cdot i t}+\beta_{3} X_{i t}+\gamma_{t}+\delta_{i}+\varepsilon_{i t}
$$

\section{Results}

The results of the main estimate, which tests Hypothesis 1, can be seen in Table 2. In columns 1 and 2 , taxation as $\%$ of GDP is regressed on the two measures of budget centralization without control for the level of public spending. Both of the budget centralization variables have the expected positive sign and non-trivial coefficient sizes. Going from the lowest to the highest positive level on the budget centralization indexes increases taxation levels by about three percentage points of GDP. However, only the contracts centralization measure is statistically significant at conventional levels. In columns 3 and 4, the level of government spending is added as a control in line with the theoretical argument that increased budget centralization increases tax levels while holding the level of public expenditure constant. In these estimates, the coefficient size of the delegation 
centralization index increases to almost four percentage points of GDP, while the level of statistical significance increases to $p<0.05$. The contracts centralization index decreases somewhat with the addition of the control of level of public expenditure but increases its level of statistical significance. These findings provide evidence in favor of the theoretical argument that, given the public expenditure level, the further centralization of the budget process increases the level of taxation. In short, substantial evidence in favor of Hypothesis 1 is found for the $15 \mathrm{EU}$ countries.

In line with the common-pool argument about taxation, government fractionalization has a statistically significant, negative effect on the level of taxation, whereas share of leftwing cabinet members has a significant, positive effect on tax levels in line with an expected partisan effect. The other control variables seem to affect the level of taxation negatively but are usually not statistically significant.

[Table 2 here]

\subsection{Coalition dynamics}

Given the results in Table 2, there seems to be substantial evidence in favor of Hypothesis 1. To test Hypothesis 2 and explore the potential effect of the interaction between budget centralization and government fractionalization, government fractionalization and the two budget centralization indexes are interacted in Table 3 to test whether budget centralization reduces the fractionalization effect on the level of taxation. In column 1, the interaction between delegation centralization and government fractionalization has the expected positive sign, with a statistically significant effect ( $\mathrm{p}$ $<0.10)$. In line with the theoretical argument, budget centralization, which makes the finance minister a more powerful agenda-setter and decision-maker in the budget process, increases in its effectiveness the more fragmented the cabinet is; presumably since higher fragmentation makes 
deviation from the finance minister's status quo agenda less likely. However, the interaction between contracts centralization and government fractionalization has a negative sign and is not statistically significant, while the constituting contracts centralization index still retains its positive and statistically significant effect. Contracts centralization increases the level of taxation given the public expenditure level but does not seem to become more effective with the increased fractionalization of the cabinet; if anything, the opposite seems to be the case.

[Table 3 here]

The effect of budget centralization contingent on government fractionalization is visualized in Figure 1. It again shows that the effect of delegation centralization on taxation levels becomes larger the more fragmented the government is, while contract centralization, if anything, becomes a less efficient way of increasing taxation levels when government fractionalization increases.

[Figure 1 here]

That the mediating effect of increased government fractionalization only seems to be present for delegation centralization might not be surprising, as this type of budget centralization actually best fits the theoretical model's notion of budget centralization with a powerful, agenda-setting finance minister. Larger fractionalization of the government coalition should make it harder to agree to remove taxation items from the revenue side of the budget already prepared by the finance minister 
when the finance minister has substantial power over the budget agenda and subsequent parliamentary and budget implementation procedures, which is the case for delegation centralization. Conversely, contracts centralization might have an overall effect on the level of taxation due to concerns within the government about not being able to balance the public budget given the fiscal targets, ${ }^{11}$ but this type of budget centralization does not become more efficient in raising taxation as government fractionalization increases. This is presumably because the effect of contracts centralization on taxation is not due to the finance minister's hard agenda-setting power and control over the taxation status quo, which becomes harder to deviate from when government fractionalization is high.

The dynamics of government fractionalization and type of budgetary institution thus seem reversed for taxation compared to public spending according to the arguments and findings of Hallerberg et al. (2009), where contracts centralization is a superior method for fiscal discipline when government fractionalization (in terms of the number of parties and ideology) is high and when coalition parties might risk running against each other in electoral campaigns (Hallerberg et al. 2009, pp. 12-51). However, the findings in Table 3 are in accordance with this article's theoretical argument that the further fractionalization of the government coalition should make it harder to deviate from the finance minister's preferred level of taxation, which serves as the status quo with high delegation centralization but not necessarily with high contracts centralization.

\footnotetext{
${ }^{11}$ As previously mentioned, the finance minister might still play an important role as "guardian" of the fiscal targets and their implementation (Hallerberg et al. 2009, p. 51), which might also include working to raise taxes to meet the financing requirements of these fiscal targets.
} 
These results suggest that budget procedures work differently for different types of fiscal policy. While the agenda-setting power of the finance minister regarding the total budget does indeed also appear to impact the level of taxation, unlike public debt accumulation (Hallerberg et al. 2009) and public spending (Martin and Vanberg 2013), a more powerful finance minister seems to increase rather than reduce the growth of this fiscal aggregate. This makes sense when assuming that the finance minister is focused on balancing the public budget, which can also be achieved via taxation increases.

There is, thus, robust evidence in favor of Hypothesis 2 when budget centralization is measured as delegation centralization, which is also in line with the theoretical model. However, to check the sensitivity of the results to an alternative measure of government fractionalization, the checks variable is replaced in the supplementary material (Appendix C) with the well-known government Herfindahl index ${ }^{12}$ from the Database of Political Institutions. The government Herfindahl index is equal to the sum of the squared seat shares of the parties in government (Cruz et al. 2016). These results are largely similar to the results in Table 3 . The moderating effect of government fractionalization on budget centralization thus seems to be robust to alternative measures ${ }^{13}$ of government fractionalization rather than a statistical artifact driven by the precise measurement of the checks variable.

\footnotetext{
12 The index goes from 0 to 1 , lower scores denoting larger government fractionalization, which should be noted when interpreting the results in Appendix C. It is also necessary to note that the government Herfindahl index only measures government size fractionalization, not ideological distances within the government.

${ }^{13}$ The results are also similar if fractionalization is measured using the govfrac variable from the Database of Political Institutions, which measures the probability of two randomly picked government deputies being from different parties (Cruz et al. 2016). Results available upon request.
} 


\subsection{Robustness tests}

The empirical analysis seems to support both Hypotheses 1 and 2, with the variation that only the effect of delegation centralization on taxation seems to increase with government fractionalization. However, concerns might be raised that the changes in budgetary procedures could be endogenous to other factors that might also affect taxation levels. One particularly concerning factor is that of European integration, which might matter for changes in budgetary procedures (Hallerberg et al. 2009, pp. 124-126) The introduction of the Economic and Monetary Union (EMU) might also have mattered for taxation levels due to the formal budget and government debt requirements in the Stability and Growth Pact. To address this issue, I redo the results from Tables 2 and 3 and include a control for whether the county is an EMU member (see Table 4). However, controlling for EMU membership does not change the core results from Tables 2 and 3. The EMU dummy itself does not seem to have any statistically significant impact on the level of taxation. The core results and the underlying theoretical argument about the link between budget centralization and tax levels still receive empirical support.

\section{[Figure 4 here]}

As an additional robustness test in Table 5, the main estimates are repeated with the addition of a control for gross government debt. ${ }^{14}$ Government fiscal crises, which are often precipitated by large government debt increases, have been found to be a predictor of government fiscal institutional reform (Hallerberg and Scartascini 2015). Furthermore, since taxes might be raised to consolidate public finances when government debt is high, the previously established relationship between

\footnotetext{
${ }^{14}$ Source: the Comparative Political Dataset.
} 
budget centralization and taxation might be endogenous to the level of government debt. However, adding the control for government debt in Table 5 changes neither the coefficient sizes, the statistical significance of the two centralization indexes nor their interaction with government fractionalization.

[Table 5 here]

The core results are apparently robust both to potential external and internal factors, which might be correlated with changes to fiscal institutions as well as the level of taxation. Hypotheses 1 and 2 and the underlying theoretical argument that budget centralization increases the level of taxation (and that government fractionalization might increase this effect), seem significantly strengthened. As a final sensitivity check, I address the issue of previous tax revenue levels. Tax systems and, thus, tax revenues generally tend to exhibit considerable inertia, so previous tax levels might influence current tax levels. However, including a lagged dependent variable with unit-fixed effects in such a relatively short panel might introduce risk of the so-called Nickell bias (Nickell 1981). Nonetheless, I rerun the full models from Tables 2 and 3 with a lagged dependent variable added to the estimates. These results can be found in the supplementary material (Appendix D). While there are some changes to the coefficient sizes of the central independent variables (which is hardly surprising given the loss of variance), the basic findings from the main analysis still receive support in these estimates. Greater centralization of the budget procedure, whether in the form of increased fiscal delegation to the finance minister or stronger fiscal contracts, increases taxation as \% of GDP. This effect increases with government fractionalization for delegation centralization but not for contracts centralization. 


\section{Conclusion}

The effect of fiscal institutions, including budget procedures, is a large and growing field in the study of public finances and their political determinants. This article has brought the issue of different budget procedures to the area of taxation, where the effects of different budget procedures have not been studied. Building on a simple common-pool argument, the article argues that budget centralization increases the level of taxation given public spending, as a more centralized budget procedure strengthens the agenda-setting power of the finance minister and renders it harder for the cabinet and parliament to remove the tax increases presented to them. This dynamic should increase with the fractionalization of the cabinet. A panel analysis of 15 EU countries produces strong evidence in favor of this argument but also that the effect differs between types of budget centralization. Centralization of the budget procedure, which delegates significant power to the finance minister, increases the level of taxation given the public spending level, an effect that increases with government fractionalization. The use of more stringent fiscal targets as a type of budget centralization increases the level of taxation within countries, but government fractionalization does not make this type of budget centralization more efficient.

The results of this article suggest that common-pool aspects of public finance and the effect of budget procedures in this area might differ between spending and revenue, which the previous literature on common-pool aspects of public finance has tended to underplay. The finding concerning the differences between types of budget centralization and their interplay with government fractionalization suggests that specific characteristics of the budget process might have great implications for whether and how veto-player dynamics affect public finance. Whether increased veto-player distance raises or reduces fiscal policy aggregates might depend on the 
specific decision-making process and rules within the budgetary framework. As recent literature suggests (Hallerberg et al. 2009, pp. 38-41; Bäck and Lindvall 2015), this might also depend on specific features of the veto players themselves, including whether coalition partners expect to be in office together again in the future. ${ }^{15}$ These issues possibly also affect taxation, where the taxationdampening effect of partisan fragmentation might be lower if parties expect to hold office together in the future. Future research might address these issues in greater detail and test whether, apart from fiscal policy, these dynamics might also be relevant for other aspects of government policymaking.

The centralization of the budget process might indeed matter for public deficits and debt accumulation by constraining public spending (Martin and Vanberg 2013), but this article shows that the centralization of the budget process might also actually restrain government deficits and debt accumulation by increasing public revenues. Budget centralization might not unequivocally serve as a tool to limit government size, at least regarding public revenue. If longer-term budget and government credit constraint are hard, then countries running large deficits due to increases in unfinanced public spending might eventually have to cut spending. Countries with decentralized budget procedures might therefore have more volatile — but on average smaller-levels of taxation and public spending in the longer term, whereas countries with more centralized budget procedures might have slightly higher — albeit more stable — average levels of public spending and taxation.

\footnotetext{
${ }^{15}$ New theoretical and empirical studies of veto-player dynamics, which consider issues of time-extended policymaking and credible commitments (Tommasi et al. 2014; Bäck and Lindvall 2015), also generate different or amended theoretical predictions vis-à-vis the effect of veto players on government policy stability and government fiscal policy. This article can be seen as yet another contribution to the amendment of the veto-player framework in budgetary politics.
} 
Given that the budget procedures in European countries seem to have become more centralized (Hallerberg et al. 2009, p. 74), a trend that might have continued with stricter fiscal rules and procedures in the aftermath of the European debt crises in the 2010s (Lledó et al. 2017), European countries might be heading in this direction. Researchers and policymakers working with budget institutions might bear this in mind in future research and when assessing the impact and desirability of more centralized budget procedures. 


\section{Acknowledgements}

I would like to thank Mathias Heinze Pedersen, Peter Kurrild-Klitgaard, Benjamin C. K. Egerod, participants at the 2017 Danish Public Choice Workshop, three anonymous reviewers and the editor of Public Choice for their help, advice and suggestions. Special thanks to Mark Hallerberg for generously sharing the data on budget procedures. 


\section{References}

Alesina, A., \& Perotti, R. (1996). Fiscal discipline and the budget process. The American Economic Review Paper and Proceedings, 86(2).

Alesina, A., Hausmann, R., Hommes, R., \& Stein, E. (1999). Budget institutions and fiscal performance in Latin America. Journal of Development Economics, 59, 253-273.

Armingeon, K., Isler, C., Knöpfel, L., Weisstanner, D., \& Engler, S. (2015). Comparative Political Data Set 1960-2013. Bern: Institute of Political Science, University of Berne.

Bäck, H., \& Lindvall, J. (2015). Commitment problems in coalitions: A new look at the fiscal policies of multiparty governments. Political Science Research and Methods, 3(1), 53-72.

Cruz, C., Keefer, P., \& Scartascini, C. (2016). Database of Political Institutions codebook, 2015 Update (DPI2015). Inter-American Development Bank. Updated version of T. Beck, G. Clarke, A. Groff, P. Keefer, \& P. Walsh. 2001. New tools in comparative political economy: The database of political institutions. World Bank Economic Review, 15(1), 165-176.

de Haan, J., Jong-A-Pin, R., \& Mierau, J. O. (2013). Do budgetary institutions mitigate the common pool problem? New empirical evidence for the EU. Public Choice, 156, 423-441.

von Hagen, J., \& Harden, I. J. (1995). Budget processes and commitment to fiscal discipline. European Economic Review, 39, 771-779.

Hallerberg, M., \& Scartascini, C. (2015). When do governments improve fiscal institutions? Lessons from financial crisis and fiscal reforms in Latin America. Economia: Journal of the Latin American and Caribbean Economic Association, 16(1), 41-76.

Hallerberg, M., Strauch, R. R., \& von Hagen, J. (2007). The design of fiscal rules and forms of governance in European Union countries. European Journal of Political Economy, 23, 338-359. 
Hallerberg, M., Strauch, R. R., \& von Hagen, J. (2009). Fiscal governance in Europe. New York: Cambridge University Press.

Lledó, V., Yoon, S., Fang, X., Mbaye, S., \& Kim, Y. (2017). Fiscal rules at a glance. Washington D.C.: International Monetary Fund.

Martin, L. W., \& Vanberg, G. (2013). Multiparty government, fiscal institutions, and public spending. The Journal of Politics, 75(4), 953-967.

Nickell, S. (1981). Biases in dynamic models with fixed effects. Econometrica, 49(6), 1417-1426.

Perotti, R., \& Kontopoulos, Y. (2002). Fragmented fiscal policy. Journal of Public Economics, 86, $191-222$.

Slemrod, J. (2004). Are corporate tax rates, or countries, converging? Journal of Public Economics, $88,1169-1186$.

Tommasi, M., Scartascini, C., \& Stein, E. (2014). Veto players and policy adaptability: An intertemporal perspective. Journal of Theoretical Politics, 26(2), 222-248.

Tsebelis, G. (2002). Veto players: How political institutions work. Princeton: Princeton University Press.

Tsebelis, G., \& Chang, E. C. C. (2004). Veto players and the structure of budgets in advanced industrialized countries. European Journal of Political Research, 43(3), 449-476.

Velasco, A. (2000). Debts and deficits with fragmented fiscal policymaking. Journal of Public Economics, 76, 105-125.

Weingast, B. R., Shepsle, K. A., \& Johnsen, C. (1981). The political economy of benefits and costs: A neoclassical approach to distributive politics. Journal of Political Economy, 89(4), 642-664. 
Wehner, J. (2010). Institutional constraints on profligate politicians: The conditional effect of partisan fragmentation on budget deficits. Comparative Political Studies, 43(2), 208-229. 


\section{Tables}

Table 1: Descriptive statistics

\begin{tabular}{|c|c|c|c|c|c|}
\hline Variable & Mean & Std. Dev. & Min & Max & Observations \\
\hline Taxation $\%$ of GDP & 38.21 & 5.64 & 26.48 & 49.48 & 276 \\
\hline Delegation centralization index & 0.59 & 0.16 & 0.23 & 1 & 276 \\
\hline Contracts centralization index & 0.73 & 0.26 & 0 & 1 & 276 \\
\hline Government fractionalization & 4.41 & 1.38 & 2 & 10 & 276 \\
\hline General government spending $\%$ of GDP & 47.49 & 7.01 & 31.08 & 70.21 & 276 \\
\hline Legislative election & 0.26 & 0.44 & 0 & 1 & 276 \\
\hline Share of leftwing cabinet members & 42.24 & 36.80 & 0 & 100 & 276 \\
\hline GDP per capita constant US dollars & $35,714.04$ & $11,416.33$ & 19,925 & 89,973 & 276 \\
\hline GDP growth & 2.69 & 2.25 & -5.92 & 11 & 276 \\
\hline
\end{tabular}

Table 2: Budget centralization and taxation

\begin{tabular}{|c|c|c|c|c|}
\hline & (1) & (2) & (3) & (4) \\
\hline Delegation centralization index & $\begin{array}{l}3.108 \\
(2.008)\end{array}$ & - & $\begin{array}{c}3.808 \\
(1.771)^{* *}\end{array}$ & - \\
\hline Contracts centralization index & - & $\begin{array}{c}3.033 \\
(1.210)^{* *}\end{array}$ & - & $\begin{array}{c}2.500 \\
(0.840)^{* * * *}\end{array}$ \\
\hline General government spending $\%$ of GDP & - & - & $\begin{array}{c}0.219 \\
(0.067)^{* * *}\end{array}$ & $\begin{array}{c}0.159 \\
(0.040)^{* * * *}\end{array}$ \\
\hline Government fractionalization & $\begin{array}{c}-0.483 \\
(0.221)^{* *}\end{array}$ & $\begin{array}{l}-0.440 \\
(0.208)^{*}\end{array}$ & $\begin{array}{c}-0.409 \\
(0.181)^{* *}\end{array}$ & $\begin{array}{c}-0.384 \\
(0.200)^{*}\end{array}$ \\
\hline Legislative election & $\begin{array}{c}0.018 \\
(0.157)\end{array}$ & $\begin{array}{l}-0.018 \\
(0.138)\end{array}$ & $\begin{array}{l}-0.002 \\
(0.147)\end{array}$ & $\begin{array}{l}-0.047 \\
(0.133)\end{array}$ \\
\hline Share of leftwing cabinet members & $\begin{array}{c}0.011 \\
(0.004)^{* * *}\end{array}$ & $\begin{array}{c}0.013 \\
(0.004)^{* * *}\end{array}$ & $\begin{array}{c}0.010 \\
(0.003)^{* *}\end{array}$ & $\begin{array}{c}0.011 \\
(0.003)^{* * *}\end{array}$ \\
\hline GDP per capita constant prices & $\begin{array}{l}-0.000 \\
(0.000)\end{array}$ & $\begin{array}{l}-0.000 \\
(0.000)\end{array}$ & $\begin{array}{l}-0.000 \\
(0.000)\end{array}$ & $\begin{array}{l}-0.000 \\
(0.000)\end{array}$ \\
\hline GDP growth & $\begin{array}{l}-0.149 \\
(0.084)^{*}\end{array}$ & $\begin{array}{l}-0.122 \\
(0.091)\end{array}$ & $\begin{array}{l}-0.057 \\
(0.092)\end{array}$ & $\begin{array}{l}-0.053 \\
(0.093)\end{array}$ \\
\hline Country-fixed effects & Yes & Yes & Yes & Yes \\
\hline Year-fixed effects & Yes & Yes & Yes & Yes \\
\hline Number of countries & 15 & 15 & 15 & 15 \\
\hline Number of observations & 276 & 276 & 276 & 276 \\
\hline Within R-squared & 0.30 & 0.39 & 0.42 & 0.45 \\
\hline
\end{tabular}

Dependent variable is taxation as \% of GDP. Country-clustered standard errors in parentheses. *p $<0.10,{ }^{* *} \mathrm{p}<0.05,{ }^{* * *} \mathrm{p}<0.01$. 
Table 3: Interaction with government fractionalization

\begin{tabular}{|c|c|c|}
\hline & (1) & (2) \\
\hline Delegation centralization index & $\begin{array}{l}-0.173 \\
(2.469)\end{array}$ & - \\
\hline Contracts centralization index & - & $\begin{array}{c}4.825 \\
(2.229)^{* *}\end{array}$ \\
\hline Government fractionalization & $\begin{array}{c}-0.951 \\
(0.385)^{* *}\end{array}$ & $\begin{array}{l}-0.117 \\
(0.299)\end{array}$ \\
\hline Delegation index $\times$ government fractionalization & $\begin{array}{c}0.856 \\
(0.434)^{*}\end{array}$ & - \\
\hline Contracts index $\times$ government fractionalization & - & $\begin{array}{l}-0.498 \\
(0.449)\end{array}$ \\
\hline General government spending \% of GDP & $\begin{array}{c}0.239 \\
(0.066)^{* * *}\end{array}$ & $\begin{array}{c}0.148 \\
(0.037)^{* * *}\end{array}$ \\
\hline Legislative election & $\begin{array}{l}-0.032 \\
(0.139)\end{array}$ & $\begin{array}{l}-0.050 \\
(0.138)\end{array}$ \\
\hline Share of leftwing cabinet members & $\begin{array}{c}0.009 \\
(0.003)^{* *}\end{array}$ & $\begin{array}{c}0.011 \\
(0.003)^{* * * *}\end{array}$ \\
\hline GDP per capita constant prices & $\begin{array}{l}-0.000 \\
(0.000)\end{array}$ & $\begin{array}{l}-0.000 \\
(0.000)\end{array}$ \\
\hline GDP growth & $\begin{array}{l}-0.068 \\
(0.087)\end{array}$ & $\begin{array}{l}-0.062 \\
(0.093)\end{array}$ \\
\hline Country-fixed effects & Yes & Yes \\
\hline Year-fixed effects & Yes & Yes \\
\hline Number of countries & 15 & 15 \\
\hline Number of observations & 276 & 276 \\
\hline Within R-squared & 0.43 & 0.46 \\
\hline
\end{tabular}

Dependent variable is taxation as \% of GDP. Country-clustered standard errors in parentheses.

$* \mathrm{p}<0.10, * * \mathrm{p}<0.05, * * * \mathrm{p}<0.01$. 
Table 4: Control for EMU membership

\begin{tabular}{|c|c|c|c|c|}
\hline & (1) & $(2)$ & (3) & (4) \\
\hline Delegation centralization index & $\begin{array}{c}3.729 \\
(1.664)^{* *}\end{array}$ & - & $\begin{array}{l}-0.570 \\
(2.216)\end{array}$ & - \\
\hline Contracts centralization index & - & $\begin{array}{c}2.439 \\
(0.797)^{* * *}\end{array}$ & - & $\begin{array}{c}4.859 \\
(2.241)^{* *}\end{array}$ \\
\hline Government fractionalization & $\begin{array}{c}-0.413 \\
(0.182)^{* *}\end{array}$ & $\begin{array}{c}-0.387 \\
(0.199)^{*}\end{array}$ & $\begin{array}{c}-0.997 \\
(0.381)^{* *}\end{array}$ & $\begin{array}{l}-0.109 \\
(0.302)\end{array}$ \\
\hline Delegation index $\times$ government fractionalization & - & - & $\begin{array}{c}0.922 \\
(0.410)^{* *}\end{array}$ & - \\
\hline Contracts index $\times$ government fractionalization & - & - & - & $\begin{array}{l}-0.520 \\
(0.448)\end{array}$ \\
\hline General government spending $\%$ of GDP & $\begin{array}{c}0.225 \\
(0.068)^{* * * *}\end{array}$ & $\begin{array}{c}0.165 \\
(0.042)^{* * *}\end{array}$ & $\begin{array}{c}0.246 \\
(0.067)^{* * * *}\end{array}$ & $\begin{array}{c}0.154 \\
(0.039)^{* * *}\end{array}$ \\
\hline Legislative election & $\begin{array}{c}0.001 \\
(0.146)\end{array}$ & $\begin{array}{l}-0.043 \\
(0.131)\end{array}$ & $\begin{array}{l}-0.030 \\
(0.138)\end{array}$ & $\begin{array}{l}-0.046 \\
(0.135)\end{array}$ \\
\hline Share of leftwing cabinet members & $\begin{array}{c}0.009 \\
(0.003)^{* *}\end{array}$ & $\begin{array}{c}0.011 \\
(0.003)^{* *}\end{array}$ & $\begin{array}{c}0.008 \\
(0.003)^{* *}\end{array}$ & $\begin{array}{c}0.011 \\
(0.003)^{* * * *}\end{array}$ \\
\hline GDP per capita constant prices & $\begin{array}{l}-0.000 \\
(0.000)\end{array}$ & $\begin{array}{l}-0.000 \\
(0.000)\end{array}$ & $\begin{array}{l}-0.000 \\
(0.000)\end{array}$ & $\begin{array}{l}-0.000 \\
(0.000)\end{array}$ \\
\hline GDP growth & $\begin{array}{l}-0.054 \\
(0.094)\end{array}$ & $\begin{array}{l}-0.050 \\
(0.094)\end{array}$ & $\begin{array}{l}-0.065 \\
(0.088)\end{array}$ & $\begin{array}{l}-0.060 \\
(0.095)\end{array}$ \\
\hline EMU & $\begin{array}{l}-0.558 \\
(0.517)\end{array}$ & $\begin{array}{l}-0.436 \\
(0.557)\end{array}$ & $\begin{array}{l}-0.636 \\
(0.476)\end{array}$ & $\begin{array}{l}-0.496 \\
(0.584)\end{array}$ \\
\hline Country-fixed effects & Yes & Yes & Yes & Yes \\
\hline Year-fixed effects & Yes & Yes & Yes & Yes \\
\hline Number of countries & 15 & 15 & 15 & 15 \\
\hline Number of observations & 276 & 276 & 276 & 276 \\
\hline Within R-squared & 0.43 & 0.46 & 0.44 & 0.47 \\
\hline
\end{tabular}

Dependent variable is taxation as \% of GDP. Country-clustered standard errors in parentheses. ${ }^{*} \mathrm{p}<0.10,{ }^{* *} \mathrm{p}<0.05,{ }^{* * *} \mathrm{p}<0.01$. 
Table 5: Control for government debt

\begin{tabular}{|c|c|c|c|c|}
\hline & (1) & (2) & (3) & (4) \\
\hline Delegation centralization index & $\begin{array}{c}3.711 \\
(1.795)^{*}\end{array}$ & - & $\begin{array}{l}-0.947 \\
(2.886)\end{array}$ & - \\
\hline Contracts centralization index & - & $\begin{array}{c}2.460 \\
(0.793)^{* * *}\end{array}$ & - & $\begin{array}{c}4.816 \\
(2.209)^{* *}\end{array}$ \\
\hline Government fractionalization & $\begin{array}{c}-0.402 \\
(0.182)^{* *}\end{array}$ & $\begin{array}{c}-0.378 \\
(0.196)^{*}\end{array}$ & $\begin{array}{c}-1.019 \\
(0.396)^{* *}\end{array}$ & $\begin{array}{l}-0.106 \\
(0.303)\end{array}$ \\
\hline Delegation index $\times$ government fractionalization & - & - & $\begin{array}{c}0.983 \\
(0.494)^{*}\end{array}$ & - \\
\hline Contract index $\times$ government fractionalization & - & - & - & $\begin{array}{l}-0.506 \\
(0.452)\end{array}$ \\
\hline General government spending \% of GDP & $\begin{array}{c}0.206 \\
(0.058)^{* * *}\end{array}$ & $\begin{array}{c}0.148 \\
(0.039)^{* * *}\end{array}$ & $\begin{array}{c}0.216 \\
(0.053)^{* * *}\end{array}$ & $\begin{array}{c}0.135 \\
(0.038)^{* * *}\end{array}$ \\
\hline Legislative election & $\begin{array}{l}-0.001 \\
(0.148)\end{array}$ & $\begin{array}{l}-0.044 \\
(0.135)\end{array}$ & $\begin{array}{l}-0.033 \\
(0.140)\end{array}$ & $\begin{array}{l}-0.047 \\
(0.140)\end{array}$ \\
\hline Share of leftwing cabinet members & $\begin{array}{c}0.010 \\
(0.003)^{* *}\end{array}$ & $\begin{array}{c}0.012 \\
(0.003)^{* * * *}\end{array}$ & $\begin{array}{c}0.009 \\
(0.003)^{* *}\end{array}$ & $\begin{array}{c}0.011 \\
(0.003)^{* * * *}\end{array}$ \\
\hline GDP per capita constant prices & $\begin{array}{l}-0.000 \\
(0.000)\end{array}$ & $\begin{array}{l}-0.000 \\
(0.000)\end{array}$ & $\begin{array}{l}-0.000 \\
(0.000)\end{array}$ & $\begin{array}{l}-0.000 \\
(0.000)\end{array}$ \\
\hline GDP growth & $\begin{array}{l}-0.067 \\
(0.085)\end{array}$ & $\begin{array}{l}-0.061 \\
(0.092)\end{array}$ & $\begin{array}{l}-0.087 \\
(0.080)\end{array}$ & $\begin{array}{l}-0.073 \\
(0.091)\end{array}$ \\
\hline Gross government debt & $\begin{array}{c}0.006 \\
(0.016)\end{array}$ & $\begin{array}{c}0.005 \\
(0.011)\end{array}$ & $\begin{array}{c}0.011 \\
(0.017)\end{array}$ & $\begin{array}{c}0.006 \\
(0.011)\end{array}$ \\
\hline Country-fixed effects & Yes & Yes & Yes & Yes \\
\hline Year-fixed effects & Yes & Yes & Yes & Yes \\
\hline Number of countries & 276 & 276 & 276 & 276 \\
\hline Number of observations & 15 & 15 & 15 & 15 \\
\hline Within R-squared & 0.42 & 0.45 & 0.44 & 0.47 \\
\hline
\end{tabular}




\section{Figures}

Figure 1: The effect of centralization contingent on government fractionalization

a: Delegation centralization

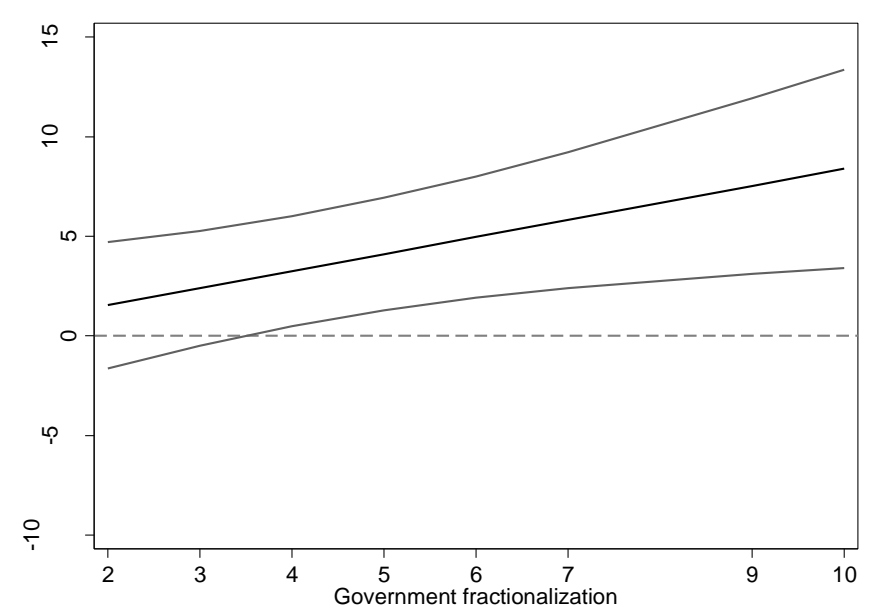

b. Contracts centralization

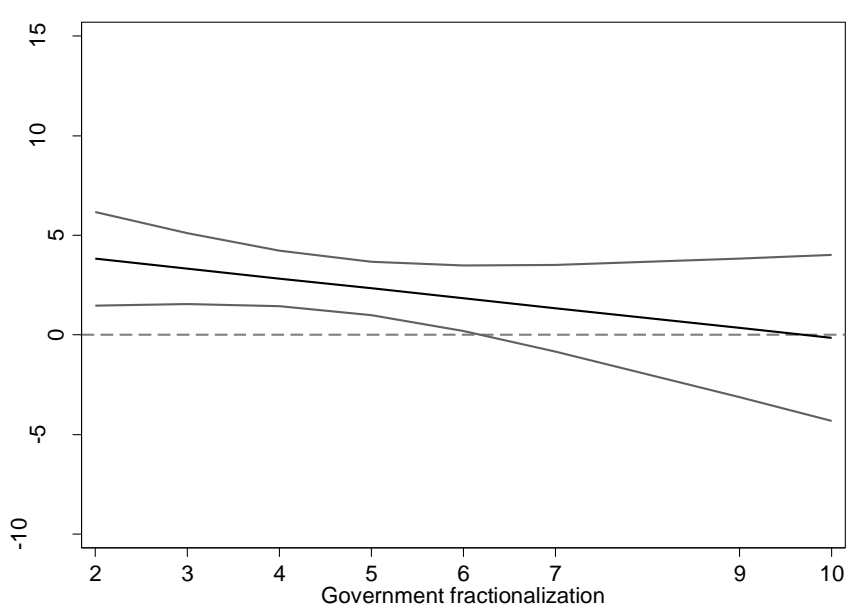

Note: Outer lines show 90\%. confidence intervals. 